\title{
Oral care in prevention of ventilator-associated pneumonia in neonatal and pediatric intensive care unit: protocol proposal
}

\author{
Lilian Tatiane Bassan, ${ }^{1}$ Maria Paula Siqueira De Melo Peres, ${ }^{1}$ Juliana Bertoldi Franco ${ }^{1,2}$ \\ ${ }^{1}$ Dentistry Division, Central Institute, University Hospital, Medical School, University of São Paulo (USP), São Paulo, SP, Brazil \\ ${ }^{2}$ Hospital Auxiliar de Suzano, University Hospital, Medical School, University of São Paulo (USP), São Paulo, SP, Brazil \\ - Conflicts of interest: none declared.
}

\section{Abstract}

Objective: to review the literature on ventilator-associated pneumonia in a neonatal and pediatric intensive care unit, the main substances and vehicles used for oral hygiene, and to propose an oral care protocol for the prevention of ventilator-associated pneumonia, prioritizing the oral comfort and providing a better quality of life. Material and Methods: search in databases from 2000 to 2018, with focus on oral care in neonatal and pediatric intensive care units, using the following descriptors: Ventilator-associated pneumonia; Aspiration pneumonia; Neonatal intensive care unit; Pediatric intensive care unit; Oral hygiene. Results: we selected 26 articles with neonatal and pediatric approach for preparation of the protocol proposal, which must be planned according to the availability of material and human resources, hospital profile, and must be based on scientific evidence. Conclusion: oral care protocols contribute for reducing the risk of infections in intensive care units, reducing the length of stay and hospital costs. Each hospital must develop its own protocol based on available scientific literature and on clinical experience of professionals involved.

Keywords: Ventilator-associated pneumonia; Neonatal intensive care unit; Pediatric intensive care unit; Oral hygiene; Dental Care.

\section{Introduction}

$\mathrm{C}$ onsidered the main cause of complications in hospital environments, infections are still a serious public health problem due to the high rates of morbidity, mortality and the increase in cost of hospitalization. The ventilator-associated pneumonia (VAP) is among the most common infections in intensive care units (ICU), being the inhalation of the contents in the oropharynx one of its possible etiologies. ${ }^{1-6}$

The Brazilian Health Regulatory Agency (Anvisa) provides the minimum requirements for the operation of an ICU and presents other providences. According to the RDC Anvisa resolution no. 7 of February 24, 2010, the neonatal (NICU) and the pediatric (PICU) ICU should be divided by age and profile of underlying disease, being classified as: NICU, destined for care of patients aged between 0 and 28 days of life; PICU, destined for care of patients aged between 29 days to 14 years or 18 years, the latter being the limit set according with the routines of the institution; mixed pediatric ICU (MPICU), destined for care of newborn and pediatric patients in a same unit, but with physical separation between the environments. ${ }^{7}$

Patients in the NICU and PICU on mechanical ventilation (MV) are highly susceptible to infections, since they have several factors such as immune system immaturity, low weight, immunosuppression, polypharmacy, use of broad-spectrum antibiotics, need for invasive procedures, enteral nutrition, in addition to factors associated with the environment and to health professionals. ${ }^{8-12}$

Even with teeth absence, many micro-organisms are found in the oral cavities due to local characteristics, as hu- midity, temperature, high tension of oxygen, and constant presence of food, making the cavity favorable to the proliferation and adhesion of microorganisms to the mucosa, alveolar ridge, tongue, palate and oropharynx, in addition to the orotracheal intubation tube. ${ }^{1,13}$

Dental care and oral hygiene are effective methods in decontamination of oral cavity, contributing to VAP prevention, and are present in several preventive measures, as well as the hydration of lips and oral mucosa. ${ }^{1}$

The literature is solidified regarding the importance of specific protocols in adult patients on MV in VAP prevention. ${ }^{1-6}$ There are few studies about NICU and PICU, and there is still no consensus on what would be the best technique to be performed in them, as well as the best substance for use, the frequency and of how to perform the removal of dental biofilm..$^{9,14-17}$

Given this, we observed the need to define an effective oral care protocol in this type of ICU, so that it can be applied with the aim of VAP prevention, providing oral comfort and improvement of the quality of life.

\section{Material and Methods}

For the preparation of this article, a descriptive, non-experimental literature review was carried out from 2000 to 2018, in the databases Pubmed, Bireme, Scopus, Scielo and Google Scholar. Studies focused on VAP and oral care with emphasis on oral hygiene protocols, substances used, cleaning methods, devices to be used and products used for hydration of oral and labial mucosa in NICU and PICU. The health sciences descriptors (DeCS) used were: ventilator-associated pneumonia; neonatal intensive care unit; pediatric 
intensive care unit; oral hygiene; prevention \& control, in Portuguese. And pneumonia, ventilator-associated; intensive care units, neonatal; intensive care units, pediatric; oral hygiene, in English. Twenty-six articles that were directly related to the subjects and considered relevant for the construction of the oral care protocol were selected.

\section{Results}

\section{Physiopathology of Ventilator-associated Pneumonia} in Neonatal and Pediatric ICU

VAP is an infection of the lower airways caused by migration and proliferation of endogenous, pathogenic, primary and secondary microorganisms, originating from other locations. It develops 48 hours after the beginning of the MV and is considered up to 72 hours after airway extubation. ${ }^{1,3-6}$ VAP is associated with the increase in the length of stay and excessive use of antimicrobials, with increase in rates of morbidity, mortality and costs. ${ }^{1,6}$ Its main etiology is the inhalation of contents in the oropharynx. ${ }^{18}$

Abuabara et al., in 2014, estimated that VAP is responsible for a cost of $\mathrm{R} \$ 748.37$ per patient, per day, in the Brazilian Unified Health System (SUS), with average increase of 10 days in hospitalization, resulting in increase of $\mathrm{R} \$ 7,000.00$ in cost, per patient, per VAP episode. ${ }^{6}$

Wehbe et al. ${ }^{17}$ performed a study that identified the major risk factors for the VAP in Pediatrics, as: prematurity $(<28$ weeks of gestation); immunological immaturity; colonization of mucosae by external agents; prolonged period of invasive $\mathrm{MV}$; non-sanitation of hands before and after handling the patient; lack of hygiene of oral cavity; unnecessary handling of patient; non-elevated decubitus; and non-performance of suctioning of oral cavity. ${ }^{12,15,16,18}$

Dal-Bó et al. ${ }^{11}$ published that the incidence rates of hospital infection reported in Brazilian NICU are $45.8 \%$, with general mortality of $12.1 \%$, and mortality from nosocomial infection in $33.8 \%$.

\section{Oral Care Protocols in Neonatal and Pediatric ICU}

Franklin et al..$^{19}$ mentioned that evidence-based protocols were established for some groups of patients, such as oncologic and hematologic children. However, they emphasize that other protocols must be established for newborns and children in ICU.

In 2012, the Institute for Healthcare Improvement (IHI) published a handbook on VAP prevention in PICU and NICU, demonstrating the main changes in relation to protocol of adults. It had the following recommendations: elevation of the head of the bed between $15^{\circ}$ to $30^{\circ}$ in neonatal units, and from $30^{\circ}$ to $40^{\circ}$ in pediatric units; prophylaxis of peptic ulcer and deep vein thrombosis as appropriate to the age and medical condition of the child; reduction of sedation in children was not recommended due to risk of extu- bation. In addition, the IHI indicated understanding of oral care appropriate to the age and risks of patients; use of chlorhexidine to hygiene in children over two months, keeping the oral cavity always clean; maintenance of the ventilator circuit every 2 hours and its exchange when with visible dirt or defective functioning; careful hygiene of hands before and after contact with patients and with the equipment; and storage of oral aspiration devices in a plastic bag when not in use. ${ }^{8,10,14,16,19,20,26}$

Ullman et al..$^{20}$ demonstrated wide variation in oral hygiene practices performed by the nursing staff of a PICU, and argued that the oral health can be better managed through institution of oral hygiene protocols based on evidence specific to children in ICU and multidisciplinary team training.

Among the oral care, the authors cite the use of substances for performance of oral hygiene, as dentifrices and fluoride solution, enzymatic solution based on lactoperoxidase, chlorhexidine in several concentrations, $0.9 \%$ saline solution, hydrogen peroxide (10 volumes), distilled or sterile water, and bicarbonate water at 3\%. These can be applied with infant toothbrush, or foam swab or sterile gauze. ${ }^{1,2,5,6,13,14,19-24}$ The hydration of lips and mucosae is recommended with substances based on lanolin, water soluble gel and/or oral lubricant to prevent oral dehydration or ulcerations. ${ }^{1,22,24}$

The current guidelines of the New Zealand Dental Association ${ }^{25}$ recommend that babies' gums whose teeth have not yet erupted should be cleaned and moistened with a small and soft toothbrush or gauze moistened with clean water or saline solution.

Santos, ${ }^{2}$ in turn, demonstrated that the use of enzymatic solution based on lactoperoxidase was effective in reducing oral microorganisms, due to its antimicrobial and moistened action.

Johnstone et al. ${ }^{14}$ described the importance of oral care in children in ICU, and that this would be determined by the patient's systemic condition, prognosis of main disease, and presence of teeth.

Padovani et al. ${ }^{24}$ developed an oral care protocol in the NICU through clinical evidence and literature review. Four substances were compared: $0.12 \%$ chlorhexidine digluconate, bicarbonate water at $3 \%, 1.5 \%$ hydrogen peroxide, and enzymatic solution. The $0.12 \%$ chlorhexidine digluconate was considered the best option due to its efficacy proved in the literature. They opted for the hydration of mucosae and lips with artificial saliva and with lanolin, respectively.

Regarding the use of substances and methods employed in the oral care in NICU and PICU for patients on MV, 26 articles with neonatal and pediatric approach were found. Of these, 18 articles indicated oral care with the use of substances recommended in children based on clinical studies and literature reviews. There were observed eight specific recommendations for Pediatrics, ${ }^{25,27-31,35,38} 5$ directed to 
Neonatology $y^{25,27-31,35,38}$, and 5 publications with recommendations for both patients. ${ }^{14,15,19,34,39}$ Only 7 of the 19 articles approached the recommendation of oral and labial hydration. ${ }^{14,15,24,27,32,36,38}$
Table 1 shows the peculiarities of the studies surveyed in relation to the type of patient, products used for oral hygiene and hydration of oral mucosae, and the devices employed.

Table 1. Authors' review in relation to products and devices used for oral hygiene in patients from neonatal and pediatric ICU

\begin{tabular}{|c|c|c|c|c|}
\hline Authors & Samples & Products & Devices & Lubricants \\
\hline $\begin{array}{l}\text { Franklin et al. } \\
2000\end{array}$ & $\begin{array}{l}\text { Children older than } 2 \\
\text { months }\end{array}$ & $0.12 \%$ chlorhexidine $(0.12 \% \mathrm{CHX})$ & Not mentioned & Not mentioned \\
\hline $\begin{array}{l}\text { New Zealand } \\
2006\end{array}$ & Toothless babies & Water and saline solution & $\begin{array}{l}\text { Soft brush, gauze, } \\
\text { swab }\end{array}$ & Not mentioned \\
\hline $\begin{array}{l}\text { Kusahara et al. } \\
2008\end{array}$ & Children & $0.12 \% \mathrm{CHX}$ & Soft brush, swab & $\begin{array}{l}\text { Unspecified } \\
\text { moisturizer }\end{array}$ \\
\hline $\begin{array}{l}\text { Pedreira et al. } \\
2009\end{array}$ & $\begin{array}{l}\text { Toothed children with } \\
\text { average of } \pm 2 \text { years. }\end{array}$ & $\begin{array}{l}\text { Placebo gel and } 0.12 \% \text { chlorhexidine } \\
\text { gel }\end{array}$ & Soft brush, swab & Not mentioned \\
\hline $\begin{array}{l}\text { Joesthone et al. } \\
2010\end{array}$ & $\begin{array}{l}\text { Newborns and children } \\
<6>\end{array}$ & $\begin{array}{l}\text { Distilled water, saline solution, fluoride } \\
\text { paste, } 0.1 \% \mathrm{CHX}\end{array}$ & $\begin{array}{l}\text { Soft brush, gauze, } \\
\text { swab }\end{array}$ & Vaseline \\
\hline $\begin{array}{l}\text { Brierley et al. } \\
2011\end{array}$ & $\begin{array}{l}\text { Toothless and toothed } \\
\text { children }\end{array}$ & $\begin{array}{l}\text { Saline solution, fluoride paste and } \\
0.12 \% \mathrm{CHX}\end{array}$ & Soft brush, swab & Not mentioned \\
\hline $\begin{array}{l}\text { Padovani et al. } \\
2012\end{array}$ & Newborns & $\begin{array}{l}\text { Bicarbonate water, hydrogen } \\
\text { peroxide, solution based on lactoperoxi- } \\
\text { dase, } 0.12 \% \mathrm{CHX}\end{array}$ & Swab, gauze & $\begin{array}{l}\text { Lanolin, artificial } \\
\text { saliva }\end{array}$ \\
\hline $\begin{array}{l}\text { Pimentel et al. } \\
2012\end{array}$ & $\begin{array}{l}\text { Toothed children older } \\
\text { than } 1 \text { year }\end{array}$ & $0.12 \% \mathrm{CHX}$ gel and $\mathrm{CHX}$ solution & Soft brush, gauze & Not mentioned \\
\hline $\begin{array}{l}\text { Sebastian et al. } \\
2012\end{array}$ & $\begin{array}{l}\text { Children between } 3 \\
\text { months and } 15 \text { years }\end{array}$ & $0.12 \% \mathrm{CHX}$ & Not mentioned & Not mentioned \\
\hline $\begin{array}{l}\text { Tinoco-Araújo et } \\
\text { al. } 2013\end{array}$ & Premature newborns & $\begin{array}{l}\text { Solution based on lactoperoxidase, } \\
\text { hydrogen peroxide, } 0.12 \% \mathrm{CHX}\end{array}$ & Gauze, cotton rods & Lanolin \\
\hline Wehbe et al. 2013 & Newborns & $0.12 \% \mathrm{CHX}$ & Not mentioned & Not mentioned \\
\hline $\begin{array}{l}\text { Stefanescu et al. } \\
2013\end{array}$ & Premature newborns & Biotene gel and sterile water & Not mentioned & Not mentioned \\
\hline $\begin{array}{l}\text { Cooper et al. } \\
2013\end{array}$ & $\begin{array}{l}\text { Toothless and toothed } \\
\text { newborns and children }\end{array}$ & $\begin{array}{l}\text { Distilled water, saline solution, fluoride } \\
\text { paste, } 0.12 \% \mathrm{CHX}\end{array}$ & Not mentioned & Vaseline \\
\hline ISHG 2014 & $\begin{array}{l}\text { Newborns / } 28 \text { days to } \\
1 \text { year / over } 1 \text { year }\end{array}$ & $\begin{array}{l}\text { Distilled water, bicarbonate water and } \\
0.12 \% \mathrm{CHX}\end{array}$ & Not mentioned & Not mentioned \\
\hline Sales et al. 2014 & $\begin{array}{l}\text { Babies with } 2 \text { to } 8 \\
\text { erupted teeth }\end{array}$ & $\begin{array}{l}\text { Distilled water, oxygenated water (10 } \\
\text { vol.) }\end{array}$ & Gauze & Not mentioned \\
\hline AMIB 2014 & $\begin{array}{l}\text { Toothed newborns and } \\
\text { children }\end{array}$ & Sterile water, $0.12 \% \mathrm{CHX}$ & Swab, gauze & $\begin{array}{l}\text { Fatty acids, } 5 \% \text { dex- } \\
\text { panthenol, artificial } \\
\text { saliva }\end{array}$ \\
\hline José et al. 2014 & Newborns & Distilled water & Not mentioned & Not mentioned \\
\hline Piau 2015 & Toothed children & $0.12 \% \mathrm{CHX}$ & Gauze & $5 \%$ dexpanthenol \\
\hline $\begin{array}{l}\text { De Cristofano et } \\
\text { al. } 2016\end{array}$ & $\begin{array}{l}\text { Toothless and toothed } \\
\text { children }\end{array}$ & $0.12 \% \mathrm{CHX}$ & Not mentioned & Not mentioned \\
\hline
\end{tabular}


Description of Clinical Protocol of Oral Care for Patients in NICU and PICU

The aforementioned literature contributed to the development of an oral care protocol for NICU and PICU, aiming to: a) improve knowledge on oral health and hygiene for nursing professionals; b) oral care maintenance; c) prevent complications due to deficient oral hygiene and dehydration of oral mucosae; $\mathrm{d}$ ) reduce the dental biofilm and decontaminate the oropharynx; e) prevent and reduce the VAP risk; f) promote oral comfort and quality of life to the patient.

Our protocol was developed based on the literature review and critical analysis of substances used, associated with our clinical experience. We recommend its implementation according with the availability, cost and accessibility of materials in the hospital environment, and with the ICU patient profile (Figure 1).
Additional guidelines were included in the protocol aiming to alert nurses and multidisciplinary teams when there is a need to change or add items to the oral care flowchart,for example, to request the presence of a dental surgeon in the case of other changes that do not fit the routine protocol.

\section{Discussion}

Due to the scarcity of data about VAP prevention in NICU and PICU, most measures implemented were based on protocols and results obtained from adult patients. ${ }^{1,6,8,9,13,14}$

Our search resulted in 26 articles that reported oral care in this particular group of patients, with only 18 articles suggesting products for oral hygiene based on clinical trials or literature reviews, showing that there is a lack of studies in these patients, and that the oral care is considered a growing demand in the NICU and PICU, and the development

\section{Oral care protocol for neonatal and pediatric ICU}

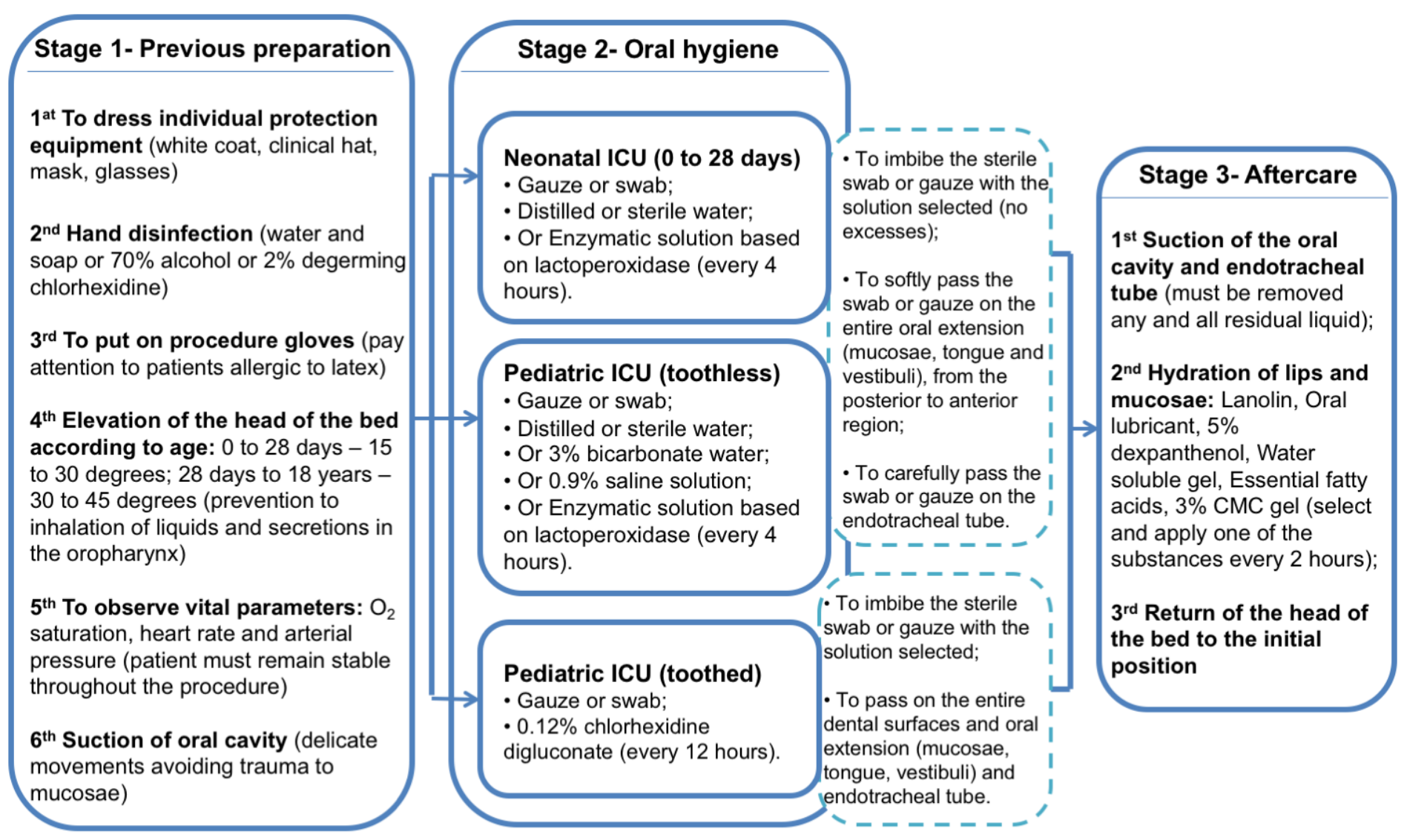

\section{Orientation in cases of:}

- Oral candidiasis: Nystatin 100,000 units - 4 times a day for 14 days. Application on adjacent mucosae and tissues (in case of previous use of $12 \%$ chlorhexidine, wait 30 minutes for application of Nystatin).

- Drooling: scopolamine - 1 drop/kg patient's weight - via oral administration or nasogastric tube or gastrostomy - until 12 years; $>12$ years: to follow posology for adults.

Figure 1. Flowchart of the oral care protocol in neonatal and pediatric ICU 
of a protocol of specific oral care becomes necessary and in accordance with the reality of each hospital, which can be built based on scientific evidence associated with the experience of professionals in the field, as the ones mentioned in this study.

VAP is cited as an increase factor in rates of permanence and mortality. ${ }^{11-13}$ It is argued that in these units the nosocomial infections tend to be more frequent ${ }^{13}$, and that it occurs most commonly in children younger than 1 year. ${ }^{18}$

Due to the absence of teeth or enteral feeding, we have the mistaken perception that there is no need for oral hygiene. However, microorganisms can adhere to other structures such as mucosae, gingival ridges, tongue, or even to orotracheal intubation tube, causing oral care to be included in the routine of general care in the NICU and PICU. ${ }^{8,14,19,20}$

Johnstone et al. ${ }^{14}$ highlighted the relationship between poor oral hygiene in ICU and the increase in accumulation of dental biofilm, and bacterial colonization of the oropharynx in children, and emphasized the importance of oral hygiene even in the absence of teeth.

Kusahara et al. ${ }^{27}$ showed that the use of the antiseptic solely provided no significant changes with regard to the presence of pathogenic microorganisms. However, when associated with the mechanical removal of the dental biofilm, the authors could observe a significant decrease in the quantity of pathogenic bacteria in the oral cavity and improvement of the periodontal health.

Marino et al. ${ }^{40}$ show that patients on MV showed oral health improvement after the brushing that could be performed with both with sponge swab and with conventional dental brush, and that both interventions were equally effective in the removal of dental biofilm and in the reduction of gingival inflammation. In addition, several studies used sponge swab as effective vehicle in the disorganization of the dental biofilm, showing the advantage of having low cost, being disposable and easy to handle., ${ }^{1,4,6,19,25,27-29,36}$

The use of sterile gauze can also be used for oral hygiene. $^{14,24,32,35,36,38}$ We do not recommend the use of cotton rods, as those used by Tinoco et al., ${ }^{32}$ due to the risk of detachment of the cotton and difficulty of removal from the oral cavity.

Among the most recommended substances for toothless newborns and babies, we have: bicarbonate water at $3 \%,{ }^{24,34}$ enzymatic solution based on lactoperoxidase, ${ }^{24,32}$ hydrogen peroxide,,$^{24,35}$ distilled or sterile water ${ }^{14,15,34,35,37}$ and saline solution. ${ }^{14,29}$ It is crucial to be careful on the guidance on adjuvant solutions to the mechanical methods used in the cleaning of the oral cavity due to risk of damage to the oral mucosa. ${ }^{3}$

Bicarbonate water at $3 \%$ is recommended do its antimicrobial and alkalizing effects. We indicate its use because no unwanted reactions were observed in the studies that related it to oral care. We do not indicate its use in newborns due to lack of scientific evidence on their safety. ${ }^{24,35}$

The enzymatic solution based on lactoperoxidase has, in addition to the antimicrobial effects cited in the studies of Santos et al. ${ }^{2}$ and Padovani et al. ${ }^{24}$ moisturizing action which assists in maintaining hydration and health of mucosae and is widely recommended in NICU and PICU.

The hydrogen peroxide (10 vol.) is another substance observed on the recommendations available due to its antimicrobial effect. However, despite cited in the literature consulted, we do not indicate its use in oral hygiene. It induces the formation of foam, which can, besides causing discomfort to the patient, be inhaled due to the swallowing reflex. $^{24,32,35}$

The use of distilled or sterile water showed no undesired effect and was indicated for being an effective method in assisting the removal of residues that may be in the oral cavity, in a safely manner since they occur in their neutral form and free from impurities. ${ }^{5,14,15,34,35,37}$

In adults, we observed that the main substance used and recommended was the $0.12 \%$ chlorhexidine digluconate due to its bactericidal and bacteriostatic effects for up to 12 hours, and with wide range of bacterial reduction both aerobic and anaerobic, Gram-positive and Gram-negative. .,2,4-6,18,23 $^{-1}$

The $0.12 \%$ chlorhexidine digluconate was recommended at different concentrations by 14 authors; however, the majority indicated its use only in PICU. No serious adverse effects or those that could not be reversed with cessation of the use of substance were demonstrated. $14,15,17,19,24,27-32,34,36,38,40$ We chose to use it in our protocol only in toothed children.

Abuabara et al. ${ }^{6}$ showed a total expense of $\mathrm{R} \$ 2.32$ per oral hygiene procedure, per patient, summing with gloves, gauze and $0.12 \%$ chlorhexidine digluconate solution, opposed to an overestimated value of R $\$ 7,000.00$ spent in SUS, at each VAP episode developed.

Besides the substances used for oral hygiene, we emphasize that a humid oral mucosa is essential for both comfort and reduction of symptoms of hyposalivation, as well as the hydration of the lips, avoiding dryness and fissures that can be gateways to microorganisms responsible for influencing the general patient's condition and causing discomfort and decrease in quality of life. Several products may be recommended for this purpose, such as lanolin, ${ }^{24,32}$ petrolatum, ${ }^{14,15} 5 \%$ dexpanthenol, ${ }^{36,38}$ essential fatty acids ${ }^{36}$ and oral water-based lubricant. ${ }^{24,36}$ We indicate the use of the gel of carboxymethylcellulose (CMC) at $3 \%$ due to the good results in relation to the hydration of oral mucosae. We recommend that these are applied regularly, according to the patient's need and availability of substances in each unit.

Aiming to guide the team to other oral diseases that may occur during hospitalization, as oral candidiasis, we advise the use of Nystatin 100,000 units, four times a day for 14 days. 
The drooling can be treated with administration of scopolamine, and has been shown to be a safe and effective method, ${ }^{32}$ avoiding rashes of the skin in the perioral region, decreasing the risk of infections and inhalation of the oropharyngeal contents.

The PICU can hospitalize patients up to their 18 years of age. During the hospitalization, which can be prolonged due to the prognosis of the underlying disease, there may occur several intraoral modifications, such as exfoliation of the deciduous teeth that must be removed in case of mobility, aiming to prevent inhalation. ${ }^{1,13,14}$

It is important for each institution to develop and establish their oral care protocols, according to the needs of its patients and availability of the team. In PICU and/or NICU we must consider the presence or absence of teeth, and which substances provide a higher benefit on the individual assessment of each patient. ${ }^{1}$

The awareness of the members of the multidisciplinary team on oral care is important in the process of prevention of infections, given that this training must be performed by the surgeon dentist.

\section{Conclusion}

The implementation of oral care protocols in hospital environments provides great benefits, especially for the improvement of oral health and removal of oral infection impacting on reduction of infections.

Our protocol was developed based on the review of the literature available and critical analysis of substances used, and must be implemented according to the availability, cost and accessibility of materials in each institution, based on the ICU profile.

We highlight the importance of research and publication of studies based on scientific evidence that improve patient care in the NICU and PICU contributing to the VAP prevention, oral comfort and quality of life.

\section{References}

1. Franco JB, Jales SMCP, Zambon CE, Fujarra FJC, Ortegosa MV, et al. Higiene bucal para pacientes entubados sob ventilação mecânica assistida na unidade de terapia intensiva: proposta de protocolo. Arq Med Hosp Fac Cienc Med Santa Casa São Paulo. 2014;59:126-31.

2. Santos PSS, Mello WR, Wakim RCS, Paschoal MAG. Uso de solução bucal com sistema enzimático em pacientes totalmente dependentes de cuidados em unidade de terapia intensiva. Rev Bras Ter Intensiva. 2008;20:154-9.

3. Branch-Elliman W, Wright SB, Howell MD. Determining the ideal strategy for ventilator-associated pneumonia prevention. Cost-Benefit Analysis. Am J Respir Crit Care Med. 2015;192(1):57-63.

4. Haghighi, A, Shafipour V, Bagheri-Nesami M., Gholipour Baradari A, Yazdani Charati J. The impact of oral care on oral health status and prevention of ventilator-associated pneumonia in critically ill patients. Aust Crit Care. 2017;30:69-73. 5. Chen Y, Mao EQ, Yang YJ, Zhao SY, Zhu C, Wang XF, et al. Prospective observational study to compare oral topical metronidazole versus $0.2 \%$ chlorhexidine gluconate to prevent nosocomial pneumonia. Am J Infect Control. 2016;44(10):1116-22.

6. Abuabara A, Weinzierk G, Weinzier, AJ. Antissepsia bucal com clorexidina para prevenir a pneumonia associada à ventilação mecânica: revisão e estudo de custos. Rev. Gestão \& Saúde. 2014;5(3):2195-219.

7. Agência Nacional de Vigilância Sanitária. Resolução-RDC n 7 , de 24 de fevereiro de 2010. [Brasil]. [access on Feb. 28, 2018]. Available from: http://www. fonosp.org.br/wordpress/wpcontent/uploads/2013/05/rdc7_anvisa-uti.pdf)

8. Bigham MT, Amato R, Bondurrant P, Fridriksson J, Krawczeski CD, Raake J, et al. Ventilator-associated pneumonia in the pediatric intensive care unit: characterizing the problem and implementing a sustainable solution. J Pediatr. 2009;154(4):582-7.

9. Esteban A, Anzueto A, Frutos F, Alía I, Brochard L, Stewart TE, et al. Mechanical Ventilation International Study Group. Characteristics and outcomes in adult patients receiving mechanical ventilation: a 28 -day international study. JAMA. 2002;287(3):345-55.

10. Mussi-Pinhata MM, Nascimento SD. Infecções neonatais hospitalares. J Pediatr (Rio J). 2001;77(1):S81-96.

11. Dal-Bó K, Silva RM, Sakae TM. Nosocomial infections in a neonatal intensive care unit in South Brazil. Rev Bras Ter Intensiva. 2012;24(4):381-5.

12. Alves C, Gomes MMF. Prevenção de infecção hospitalar em unidade de terapia intensiva neonatal. Unisa. Br. 2002;3:63-9.

13. Kusahara DM, Canezin CCDS, Peterlini MAS, Pedreira MDLG. Colonização e translocação bacteriana orofaríngea, gástrica e traqueal em crianças submetidas à ventilação pulmonar mecânica. Acta Paulista de Enfermagem. 2012;25(3):393-400.

14. Johnstone L, Spence D, Koziol-McClain J. Oral hygiene care in the pediatric intensive care unit: practice recommendations. Pediatr Nurs. 2010;36(2):85-96. 15. Cooper VB, Haut C. Preventing ventilator- associated pneumonia in children: an evidence-based protocol. Crit Care Nurse. 2013;33(3):21-9.

16. ANVISA. Agência Nacional de Vigilância Sanitária. Pediatria: Prevenção e Controle de Infecção Hospitalar. Ministério da Saúde, Brasília-DF. 2006.

17. Wehbe MAM, Lustosa SAS, Rocha APF, Oliveira IVD. Pneumonia associada à ventilação mecânica em neonatologia: um estudo retrospectivo. Resid Pediatr. 2015;5(3):118-21.

18. Centers for Disease Control and Prevention. Ventilator-associated pneumonia (VAP) event. Device Assoc Events. January 2012:6:1-6:13. [access on Feb. 28, 2018]. Available from: http:// www.cdc.gov/nhsn/pdfs/pscmanual/6pscvapcurrent.pdf.

19. Franklin D, Senior N, James I, Roberts G. Oral health status of children in a paediatric intensive care unit. Int Care Med. 2000;26(3):319-24.

20. Ullman A, Long D, Lewis P. The oral health of critically ill children: an observational cohort study. J Clin Nurs. 2011;20(21-22):3070-80.

21. Kusahara DM, Peterlini MAS, Pedreira MD LG. Colonização orofaríngea de crianças à admissão em uma unidade de cuidados intensivos. Acta Paulista de Enfermagem. 2007;20(4):421-7.

22. Santos LM, Matos MO, Santos VEP. Higiene oral em crianças ventiladas mecanicamente na unidade de cuidados intensivos: análise de uma prática. Cuid Fundam Online. 2011;3(3):2320-8.

23. Tablan OCAL, Besser R, Bridges C, Hajjeh R. Guidelines for preventing health-care-associated pneumonia, 2003 recommendations of the CDC and the Healthcare Infection Control Practices Advisory Committee. Respir Care. [Guideline Practice Guideline]. 2004;49(8):926-39.

24. Padovani MCRL, Souza SAB, Anna GRS, Guaré RO. Protocolo de cuidados bucais na Unidade de Tratamento Intensivo Neonatal. Rev Bras Ter Intensiva. 2012;14(1):71-80.

25. New Zealand Dental Association (2006). How to look after your child's teeth. [access on Feb. 28, 2018]. Available from: https://www.nzda.org.nz/pub/

26. Institute for Healthcare Improvement. How-to-Guide: Prevent Ventilator-Associated Pneumonia. Cambridge, MA. 2012. [access on Feb. 28, 2018]. Available from: http://www.ihi.org

27. Kusahara DM, Pedreira MLG, Peterlini MAS. Protocolo para higiene oral de crianças submetidas à ventilação pulmonar mecânica. Rev Soc Bras Enferm Ped. 2008;8(1):37-44.

28. Pedreira ML, Kusahara DM, de Carvalho WB, Núñez SC, Peterlini MA. Oral care interventions and oropharyngeal colonization in children receiving mechanical ventilation. Am J Crit Care. 2009;18(4):319-28.

29. Brierley J, Highe L, Hines S, Dixon G. Reducing VAP by instituting a care bundle using improvement methodology in a UK paediatric intensive care unit. 
Eur J Pediatr. 2012;171(2):323-30.

30. Pimentel, ELC. Avaliação da eficácia de um protocolo de higiene bucal na prevenção de infecções no pós-operatório infantil em crianças submetidas à cirurgia cardíaca [tese]. Rio de Janeiro: Instituto de Pesquisa Clínica Evandro Chagas, Programa de Pós-graduação em Cardiologia e Infecção, 2012.

31. Sebastian MR, Lodha R, Kapil A, Kabra SK. Oral mucosal decontamination with chlorhexidine for the prevention of ventilator-associated pneumonia in children-a randomized, controlled trial. Pediatr Crit Care Med. 2012;13(5):305-10. 32. Tinoco-Araujo JE, Araújo DFG, Barbosa PG, Santos PSDS, Medeiros AMCD. Candidíase invasiva e alterações bucais em recém-nascidos prematuros. Einstein (São Paulo). 2013;11(1):71-5.

33. Stefanescu BM, Hétu C, Slaughter JC, O'Shea TM, Shetty AK. A pilot study of Biotene OralBalance ${ }^{\circ}$ gel for oral care in mechanically ventilated preterm neonates. Contemp Clin Trials. 2013;35(2):33-9.

34. Instituto de Saúde e Gestão Hospitalar - ISGH. Pneumonia associada à ventilação mecânica - Eixo Pediátrico [protocolo]. 2014. [access on Feb. 28, 2018]. Available from: http://www.isgh.org.br/intranet/images/Servicos/Protocolos/ isgh_protocolo_pav_ped_atulizado.pdf.

35. Sales AB, Palud L, Schwartz JP, Pinto MHB, dos Santos EB. Comparação entre dois métodos de higiene bucal em bebês no controle de Streptococcus spp e
Candida. Rev Gestão \& Saúde. 2014;11:18-21.

36. Associação de medicina intensiva brasileira - AMIB. Departamentos de odontologia e enfermagem. 2014. [access on Feb. 28, 2018]. Available from:http:// www.amib.org.br/fileadmin/user_upload/amib/Institucional/AMIB-RecomendacoesHigieneBucal-PacientePediatrico.pdf.

37. Jose JD, Lucio DS, Perugini MR, Stipp AT, Silva LM, Perugini VH, et al. Prevenção de pneumonia associada à ventilação mecânica em neonatologia. J Infect Control. 2015;4(1):1-5.

38. Piau CGBC. Estudo clínico controlado da microbiota bucal de pacientes internados em UTI pediátrica após aplicação de protocolo de profilaxia bucal [tese]. Brasília: Universidade de Brasília, Programa de Pós-graduação em Ciências da Saúde, 2015.

39. De Cristofano A, Peuchot V, Canepari A, Franco V, Perez A, Eulmesekian P. Implementation of a Ventilator-Associated Pneumonia Prevention Bundle in a Single PICU. Pediatr Crit Care Med. 2016;17(5):451-6.

40. Marino PJ, Hannigan A, Haywood S, Cole JM, Palmer N, Emanuel C, et al. Comparison of foam swabs and toothbrushes as oral hygiene interventions in mechanically ventilated patients: a randomised split mouth study. BMJ Open Respir Res. 2016;3(1):e000150.

\section{Mini Curriculum and Author's Contribution}

1. Lilian Tatiane Bassan - DDS. Contribution: study conception and design; standardization of the methodology; data interpretation; manuscript preparation; manuscript writing; critical review and final approval.

2. Maria Paula Siqueira de Melo Peres - DDS and MSc. Contribution: manuscript preparation; manuscript writing; critical review and final approval.

3. Juliana Bertoldi Franco - DDS. Contribution: study conception and design; standardization of the methodology; data interpretation; manuscript preparation; manuscript writing; critical review and final approval.

Submitted: 03/15/2018 / Accepted for publication: 08/05/2018

\section{Corresponding Author}

Juliana Bertoldi Franco

E-mail: juliana.franco@hc.fm.usp.br 